\title{
In the Lipaei Islands
}

\section{George Yeld Editor}

To cite this article: George Yeld Editor (1905) In the Lipaei Islands, Scottish Geographical Magazine, 21:7, 347-352, DOI: 10.1080/00369220508733584

To link to this article: http://dx.doi.org/10.1080/00369220508733584

册 Published online: 27 Feb 2008.

Submit your article to this journal $\widetilde{ }$

III Article views: 3

Q View related articles $₫$ 
crater is now seen to be filled up by ejecta which prolong the slope of the Sciara upwards over what was previously its site, while the bocca itself remains in all probability really in its former position, though apparently on the slope of the Sciara instead of on its edge.

It will be interesting to future visitors to see whether the volcano will continue to prolong the slope of the Sciara much further upwards, or whether a paroxysmal explosion will occur which will clear the great crater again.

\section{IN THE LIPARI ISLANDS. ${ }^{1}$}

\section{By GEORGE YELD, Editor of the Alpine Journal.}

ON April 14, 1904, Dr. Tempest Anderson and I, in company with Dr. Cool and Herr Philip, arrived at Milazzo, the ancient Mylæe, a little town at the southern end of the promontory of the same name in the NE. of Sicily. We drove to the. Albergo Genova, where we afterwards spent the night. Half-a-dozen street arabs pertinaciously thrust their services upon us as luggage-carriers, and amused us much at small expense. The same evening we visited the castle on the hill to the north. On the western side of the promontory, much of which was covered with olive yards, was a charming little bay; in one or two places where a gap in the cliffs was less steep a stream of olives, so to speak, flowed down to the shore. The smoke of Stromboli was visible over not quite the highest point of the olive yards. But the great feature of the view was Etna-vast, even overwhelming in size. The parasitic cones on the W., or probably SW., ridge of it to Anderson's educated eye spoke volumes, but to me the glimpses of torrent beds and little towns perched on steep hills were more eloquent. The sunset was glorious.

The next morning on the most peaceful of seas and an ancient mail-boat we crossed the Lipari. On the east side of the Milazzo promontory the olives came down to the very edge of the shore. We noticed a line of caves just above the present water-line-perhaps six feet above itwhich would mean, so Anderson explained to me, that the land had risen -in the same way that at Pozzuoli the land has gone down and risen again in historic times. Etna was still the great feature of our view.

At Lipari we put up at the Hotel Traina, where Signor Traina did his best for us. The house is, like the other houses in Lipari, flat-roofed, and by climbing a ladder it was possible to reach a higher roof, from which one could see the little bay. The accommodation was, of course, somewhat primitive, but we were fairly comfortable. We spent the rest of the day in a visit to San Calogero and its hot springs on the west side of the island, the town of Lipari being on the east coast.

On the way back we left the main track, and turning to the right after covering some little distance gained a most lovely view of the wastes of Vulcano. In the narrowest part of the path I met a small cow in charge of a little child, who endeavoured to secure the mastery by means of a rope, but the cow acted as leading guide; the child had

1 Reprinted from the Alpine Journal for May 1905. 
even less to say as to the route taken than the feeblest traveller that ever climbed the Breithorn. Whilst in search of flowers I lost the rest of our party, and returned alone through some of the deepest chasms that we came across. The soil is friable, and the rains wash it away easily, so that many of the paths are like deep ditches.

On the next day, April 16, Dr. Anderson and Herren Cool and Philip, with Francesco Conti, an English-speaking native whom we had engaged as servant, and who made himself exceedingly useful, went to Filicudi. I went with them as far as Malfa, in the island of Salina. I ought to have explained that, thanks to the good offices of Dr. Linden of the Zoological Station at Naples, we had engaged a small steamer of about sixty tons, the property of S. Gaetano Saltalamacchia, of Lipari, so that we could go where we liked when we liked, unless AElus had forgotten to turn the key on his riotous gang of winds, as was once or twice the case.

When we had rounded a little cape we caught sight of the small white town of Canneto, behind which is a mountain of pumice stone. This is the only place in the world, I believe, where pumice stone can be got without grit (or anything that will scratch) in it, and practically Canneto furnishes the world with pumice stone. A little further we saw the Campo Bianco and Roccie Rossi. The Montagna delle Pauvre in Salina then showed his fine broad wedge.

At Malfa, where the footing, though steep, was less uncertain than on the little steamer, I had the good fortune to meet with S. Joseph Bongiorno, who had lived some years in Melbourne and spoke English perfectly.

Before I met with him I had been for a delightful walk on the hillside above Malfa, and had noticed that the children seemed better cared for and more intelligent than those of Lipari. Signor Bongiorno, who is a very keen educationist, explained to me their educational system. The children-there were then eighty-four boys and seventy-five girls under instruction-remain at school from the age of six till they get a leaving certificate. I learned much, too, of the fruits and flowers of Salina ; amongst the former are figs, almonds, peaches, nectarines, apricots, different sorts of apples and pears, very fine cherries, blackberries, and nespoli. The vines have suffered severely from phylloxera, and consequently the once flourishing trade in wine, especially Malvasia, has been sadly reduced. I returned to Lipari by the mail-boat. In the evening our party at the Traina was increased by a professor from Belgrade and a painter from Geneva.

On the 17 th the rest of the party went to Panaria, leaving me behind in Lipari. The sea was so rough that they were not able to land at the usual spot, though they managed to do so in another place with considerable difficulty. I spent the day wandering about the hills.

On the 18th we all went to Stromboli in the little steamer. We inspected Panaria and Basiluzzo at close quarters, and saw a small fleet of boats engaged in collecting sponges. Just as we got close to the shores of Stromboli a most curious gale assaulted us; it seemed to blow the fine spray over us from all sides at the same time. I do not think 


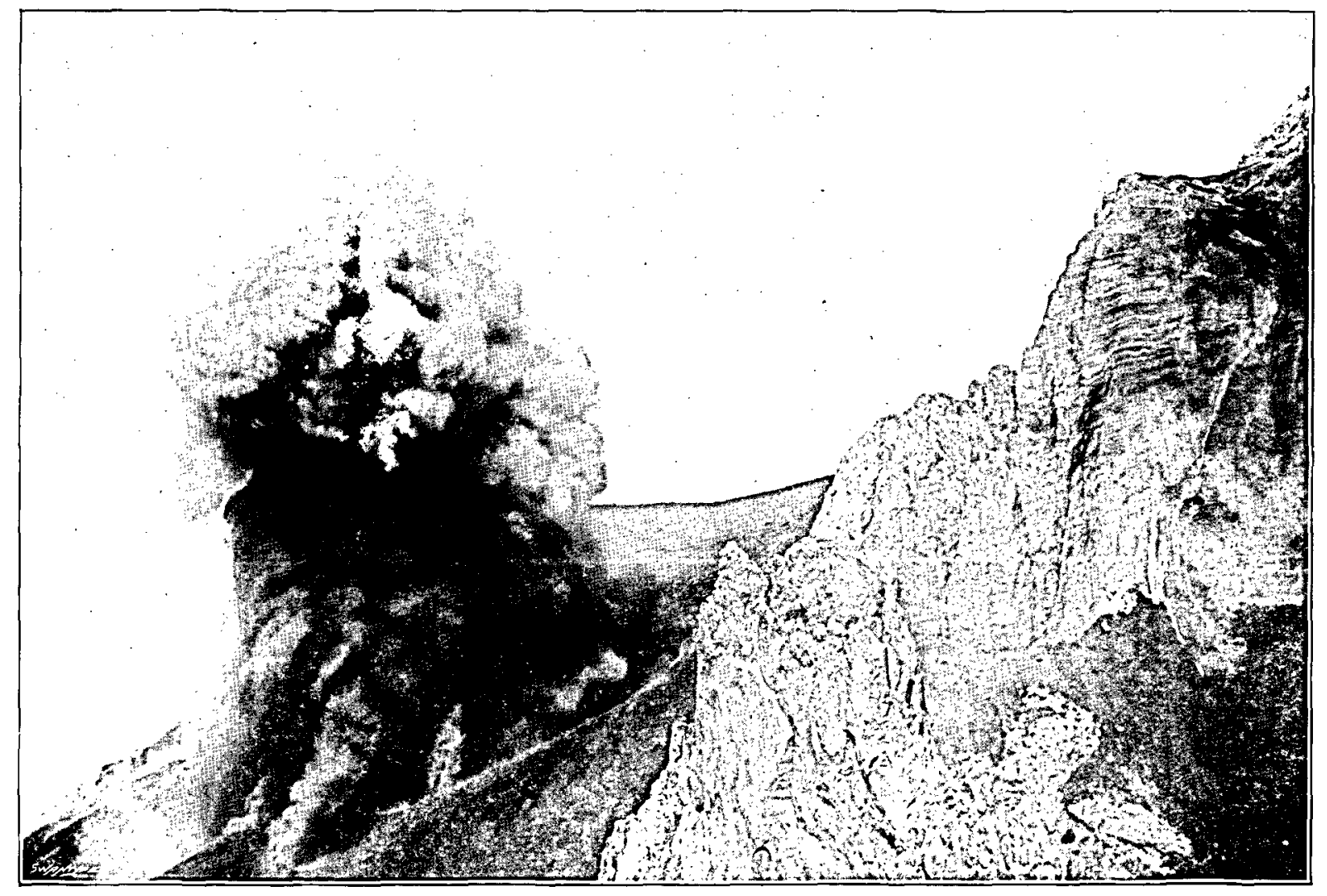


it lasted more than five or ten minutes. We passed close by the Sciara, and saw many big stones engaged in free gymnastics. "They was very. big large stones; they jump in water very much high."

When we had rounded the semaphore our captain said that it was too rough to land at the usual place, and that the steamer's own boat was too small for safety in such a sea. So he proceeded to invite the natives to send out a boat to us by whistling for all the steamer was worth. By and by, in response to this deafening appeal, a boat came out. I found a place in the bottom of it, and, as my head was just level with the water, I was able to appreciate properly the size of the waves. The boatmen, assisted by our servant, Francesco Conti, who thoroughly understands boats himself, landed us very cleverly. They waited for a big wave and rode shorewards upon it; then the people on the beach lent a hand; and we got ashore with nothing worse than a slight wetting.

Of our doings on Stromboli I need say little, as Dr. Anderson's paper is devoted to that famous volcano. We found accommodation at the house of Don Francesco Renda, to whom our best thanks are due. We made two ascents of Stromboli. On the first in splendid weather we saw everything to perfection, and the mountain was kind enough to give a special matinée, so to speak, for our satisfaction.

We began the ascent through vineyards where the vines were trained on low trellises and fenced with reeds to protect them from the wind-driven sand. Higher up there were some olives, which seemed to spread themselves out flatly to catch as much sun as possible and avoid the winds as well as they could. Higher still we found capers and willows growing in shifting volcanic dust; the latter provided the tying material for fastening the vines to the trellises. After passing through a paradise of cistus we reached in about an hour and three-quarters from the start the first of a number of big ridges of red rock (lava and tuffs, my companion said) and saw the sea off the NE. coast of the island. We of course halted to study the Sciara. The volcano itself with its scarred rocks, black volcanic dust-exuding sulphur, and many fumaroles and periodic explosions, suggested mine and breach and the brazen throat of war; but turn your head and you have vineyards, white houses, a sapplire sea, and Strombolicchio like Neptune's trident rising from the waves. We saw a fine hawk, a barking crow, many swallows, and several butterflies on our way up. We did not see any quails, though they are caught at this season, but this year so far only two had been netted.

Leaving the apparent top we walked down a ridge to the Ginostra side of the mountain. Thence we witnessed many terrific eruptions, huge stones visibly red-hot being hurled high into the air. Many took a salto mortale down the Sciara and added to that huge mass which stretches for thousands of feet into the depths of the sea, so that were the waters to dry up and show Stromboli in the fulness of his stature we should gaze in wonder on a masterpiece of flamboyant architecture. ${ }^{1}$

On our second ascent rain began to fall quite early in the climb, and 
long before we reached the top thick mist prevented us from seeing more than a few yards. Near the top the mist lifted slightly, and I found some rocks near a shelter hut used by signallers, on which on a sunny day I fancy one might have scrambled about with satisfaction. The bad weather was a great disappointment, as it prevented Anderson from photographing various details of the mountain-the object of our second ascent.

But it was obviously useless to wait; the wind blew, the rain drove in our faces, the mountain seemed to swear at us. I have some recollection that the compliment was returned. In brief we departed re infecta.

On the 23rd we returned to Lipari by the mail boat Toscana, our own little steamer having left us on the 20th with Herren Cool and Philip on board. The captain very politely, at Anderson's request, took us round the north side of the island, so that we again saw the Sciara. We landed at Canneto and had a pleasant walk to Lipari.

We spent our last day in a visit to Vulcano and Vulcanello. Conti found us a boat. With Conti and the two boatmen we made a party of five, and were attended by three dogs. The sea was calm, and we had a very pleasant row. A boat from Vulcano passed us, laden with dried broom for the ovens of Lipari. The shore scenery of Lipari varied much. We passed a curious half-cleft rock, called, from its appearance, "The Scissors." Here there were great cliffs, here a fine cirque with vines coming down to the shore. At the Fossa del Capistello Conti landed to secure certain specimens of rock. Two fishermen's sailingboats in the distance after we had passed the end of Lipari looked exactly like a couple of sea-gulls.

The colouring of Vulcanello was a striking red, as if the mountain were still red-hot. We turned into the Porto di Levante and landed near the Faraglione not far from the house at which our friend S. Narlian so hospitably entertained Dr. Anderson on his previous visit to Vulcano in 1888. The mountain Vulcano looked an absolute desolationfurrowed, scarred, ruined. Five or six fumaroles, one larger than the rest, were smoking. At the foot of the mountain was a great thicket of broom, richly coloured and richly scented. When walking through it, if you shut your eyes, you might have imagined yourself in an English clover field in full bloom, so similar was the fragrance. The path mounted rapidly; in parts it seemed to be cut in almost solid sulphur. The crater of Vulcano I can only compare to a deep dried-up brick-pond. But it was very interesting, especially as Anderson replied at once to all my questions as to fumaroles, bombs, and the other details of a volcano's outfit.

After visiting the highest point of the mountain Dr. Anderson and Conti returned the same way, with a view to further examination of certain fumaroles, whilst I chose a direct route for myself. It was steep but much shorter, and, like most volcabic climbing, very destructive to one's boots.

We then, after a visit to the Villa Narlian, where we were very hospitably received, went on to Vulcanello, the boat having been sent round to await us. We thoroughly examined the crater and then 
descended to the sea ; the cliff just above the water gave us a little scramble before we reached our boat. The old rocks on Vulcanello were red, the newer ones dark-coloured. Then we returned to Lipari after a most enjoyable day. It is true that there was a slight haze, but the cool air, the warm sun, the clear blue sea, the wondrous red of the volcanic rocks, and the fervid gold of the richly-scented broom thickets compose a memory, now rendered all the more vivid, as I write, by the rigours of an Arctic April in England.

It will have been clear from what I have said that we found little climbing in the Liparis, but nevertheless our holiday was exceedingly pleasant. . In one respect these islands recall one of the greatest delights of the Alps. They are rich in flowers. Cistuses, white and purple, brooms in several varieties, a fine orchis or two, the red gladiolus in the corn (in Lipari), Iris Sisyrinchium-in one place in Lipari I counted forty blossoms together-occur to me at once. Arundo donax (the giant reed), opuntias and yellow euphorbias (I fancy the native name is "frasca") were almost everywhere to be seen. My friend at Malfa spoke also of jonquils and narcissi as growing wild, and on Vulcanello there were large numbers of pancratium, which I take to be Tennyson's " milky-belled amaryllis." In the garden of the villa on Vulcano were oleanders, mignonette, rosemary, ivy-leaved pelargoniums, verbenas, heliotrope, and wistarias; nor do these exhaust the list. But for me personally the broom will always be the flower of the Liparis. I ought, perhaps, to mention that there was a fine date palm in Don Francesco Renda's garden, bearing fruit-and good fruit too, experto credite.

But I must not forget to point out the special charm of these scrambles in the Liparis. The mountains rise out of the sea, and what the green alp is to the great alpine peak the blue sea is to Stromboli and his fellows. To-day the winds are busy, the dark purple waters are rough, and the angry surges are heavily crested with foam. To-morrow the sunbeams will sleep on the waveless blue and but the slightest fringe of white be seen on the black volcanic sand of the shore. But, look what way you will, your eyes will fall upon the sea, and when memory hereafter calls up recollections of the Liparis the sea will be the setting of every picture! And such a sea! The peacock's neck-the opal, and emerald, and sapphire-the bluest of radiant flowers-the sumptuous purple of wine have all been used in comparisons to indicate its glorious colouring; yet after all the Mediterranean, like sunrise on the Alps, cannot be described in words; it must be seen to be appreciated.

And in yet one other respect the Liparis will bear comparison with -nay, exceed-the Alps - in the human interest. "A very dull person," as Sir Martin Conway observes ${ }^{1}$ when insisting on this feature of the Alps, "looks interesting when beheld down a vista of several centuries." What then shall we say of the Phœnicians, Greeks, Carthaginians, not to mention AEolus, Deiopea, Calypso, whose shadowy forms haunt the Sicilian waves, the fairest part of the Mid Sea, that, as George Eliot has finely said, "moans with memories"? I wonder, by the way, whether 
Juno was as good as her word and Eolus gained the promised Deiopea. If so, no doubt Vulcano and Stromboli gave a special pyrotechnic display at the nuptials.

\section{SCOTTISH PLACE-NAMES AND SCOTTISH SAINTS.}

\section{By Ralph Richardson.}

Axong the many provinces of geography, that of the etymology of place-names is one of the most fascinating and the most difficult. While the ancient inhabitants of Scotland often followed the admirable practice of naming a place after its natural features, they occasionally named it after a favourite saint. It is surprising how many Scottish placenames thus originated. Appended to this paper is a by no means complete list of Scottish place-names derived from the multitude of Scottish saints who appear to have flourished from the beginning of the fifth to the beginning of the twelfth century.

In the preparation of this list reliance has been placed mainly on two recognised authorities : Bishop Forbes's Kalendars of Scottish Saints (Edinburgh, 1872), and Rev. James B. Johnston's Place-Names of Scotland (second edition, Edinburgh, 1903), while the recently issued Calendar of Scottish Saints, based on Bishop Forbes's work, by Dom Michael Barrett of Fort Augustus Abbey, has also been consulted.

The geographical distribution of these saintly place-names is interesting from several points of view. So many of the Scottish saints were of Irish origin that their traces are naturally mostly found in the western parts of Scotland. They participated in that wave of migration from Ireland which brought the Scots to Argyll, which was conquered or colonised by the Scots before the end of the fifth century. The coming of the Scots to Argyll synchronises with the period of our oldest Scottish saints.

Besides this, however, the influence of many of the early saints radiated from Iona, on which St. Columba and his companions landed from Ireland in A.D. 563. We are consequently not surprised to find in the following statement of the number of saintly place-names in each Scottish county (according to the list appended to this paper) that the county of Argyll contains by far the greatest number of such placenames :-

Northern Counties.-Shetland 2, Orkney 12, Caithness 4, Ross and Cromarty 9, Inverness 10 . In all, 37 place-names in the appended list.

Nortit-Eastenn.-Nairn 0, Elgin 3, Banff 4, Aberdeen 19. In all, 26. Western.-Argyll 52, Bute 10, Dumbarton 3, Renfrew 4, Ayr 13. In all, 82.

Souti-WESTERN.-Kirkcudbright 6, Wigtown 8. In all, 14. Southern.-Dumfries 10, Roxburgh 4, Berwick 2. In all, 16. 